\title{
Antifungal Activity of 14-Helical $\beta$-Peptides against Planktonic Cells and Biofilms of Candida Species
}

\author{
Namrata Raman ${ }^{1}$, Myung-Ryul Lee ${ }^{1}$, David M. Lynn ${ }^{1,2, *}$ and Sean P. Palecek ${ }^{1, *}$ \\ 1 Department of Chemical and Biological Engineering, University of Wisconsin-Madison, \\ 1415 Engineering Drive, Madison, WI 53706, USA; E-Mail: nraman2@wisc.edu \\ 2 Department of Chemistry, University of Wisconsin-Madison, 1415 Engineering Drive, Madison, \\ WI 53706, USA; E-Mail: mrlee2@wisc.edu
}

* Authors to whom correspondence should be addressed; E-Mails: dlynn@engr.wisc.edu (D.M.L.); palecek@engr.wisc.edu (S.P.P.).

Academic Editor: Dacheng Ren

Received: 10 July 2015 / Accepted: 4 August 2015 / Published: 13 August 2015

\begin{abstract}
Candida albicans is the most prevalent cause of fungal infections and treatment is further complicated by the formation of drug resistant biofilms, often on the surfaces of implanted medical devices. In recent years, the incidence of fungal infections by other pathogenic Candida species such as C. glabrata, C. parapsilosis and C. tropicalis has increased. Amphiphilic, helical $\beta$-peptide structural mimetics of natural antimicrobial $\alpha$-peptides have been shown to exhibit specific planktonic antifungal and anti-biofilm formation activity against $C$. albicans in vitro. Here, we demonstrate that $\beta$-peptides are also active against clinically isolated and drug resistant strains of $C$. albicans and against other opportunistic Candida spp. Different Candida species were susceptible to $\beta$-peptides to varying degrees, with $C$. tropicalis being the most and $C$. glabrata being the least susceptible. $\beta$-peptide hydrophobicity directly correlated with antifungal activity against all the Candida clinical strains and species tested. While $\beta$-peptides were largely ineffective at disrupting existing Candida biofilms, hydrophobic $\beta$-peptides were able to prevent the formation of $C$. albicans, $C$. glabrata, $C$. parapsilosis and $C$. tropicalis biofilms. The broad-spectrum antifungal activity of $\beta$-peptides against planktonic cells and in preventing biofilm formation suggests the promise of this class of molecules as therapeutics.
\end{abstract}

Keywords: Candida albicans; Candida glabrata; Candida tropicalis; Candida parapsilosis; biofilms; $\beta$-peptide; antimicrobial peptide; antifungal; hydrophobicity 


\section{Introduction}

Candida albicans is the most common cause of fungal infections in humans, with a high mortality rate of 30\%-60\% associated with systemic Candida infections [1,2]. C. albicans infections can be life-threatening in immune compromised individuals, such as those suffering from AIDS or cancer, and organ transplant recipients on immunosuppressive drugs [3-9]. Further, candidemia, the presence of Candida in the bloodstream, is often associated with the presence of an indwelling medical device such as a central venous catheter, cardiac pacemaker, urinary catheter, or orthopedic implant $[1,4,10,11]$. C. albicans form biofilms on the surfaces of these devices and serve as a reservoir of infectious cells [12-14]. While there are drugs that are active against $C$. albicans, they act on few specific molecular targets, and drug-resistant $C$. albicans strains lead to reduced efficacy of these drugs in certain cases $[15,16]$. Further, many of these drugs exhibit decreased effectiveness against $C$. albicans biofilms $[17,18]$.

Motivated by the need to develop novel antifungal therapies targeting essential organelles or pathways within the pathogen that cannot easily be bypassed through cell mutations, antimicrobial peptides (AMPs), also known as host defense peptides, have been investigated as potential antifungal drugs $[19,20]$. While these compounds target a vital component of the cell, the cell membrane, these native peptides exhibit low stability and activity in physiological media and are susceptible to proteolytic degradation in vivo [21,22]. Inspired by these naturally occurring AMPs, various groups have designed synthetic analogues that retain or improve the antimicrobial membrane disrupting activities of natural AMPs but possess improved physiological stability in vitro and in vivo [23-26]. One class of such molecules is helical oligomers of $\beta$-amino acids. These $\beta$-peptides have shown promise as antibacterials and antifungals [27-30].

We have demonstrated that certain 14-helical $\beta$-peptide structural features, specifically global amphiphilicity with an intermediate hydrophobicity, are essential for specific antifungal activity against planktonic C. albicans [29,31]. However, it is unclear what relationship exists, if any, between the structure of 14-helical $\beta$-peptides and their activity against $C$. albicans biofilms, which are more prevalent and difficult to treat in the context of medical device-associated infections. Further, the activity of 14-helical $\beta$-peptides has not been investigated in other Candida spp. While C. albicans is the predominant causative agent of fungal infections in humans, the number of other Candida species causing fungal infections is on the rise [4,7,32,33]. Specifically, C. glabrata, C. parapsilosis and C. tropicalis are increasingly becoming among the most commonly isolated pathogens causing fungal infections [33-37]. These three species are also capable of forming biofilms to varying extents and the presence of biofilms is a virulence factor that has been associated with increased mortality during infection [32,38].

In this study, we used structural features of $\alpha$-helical AMPs as a guide to design 16 globally amphiphillic 14-helical $\beta$-peptides with approximately three residues per turn. $\beta$-peptides can adopt a number of different secondary structures, including the 14-helix, which consists of 14-membered rings stabilized by hydrogen bonding between the $\mathrm{O}$ of the $\mathrm{C}=\mathrm{O}$ at the $i$ position and the $\mathrm{H}$ in the backbone $\mathrm{H}-\mathrm{N}$ at the $i$-2 position [28,39]. These peptides were comprised of 9 or $10 \beta$-amino acids, exhibited a net charge of +4 , and contained at least one helix-stabilizing cyclic aminocyclohexane carboxylic acid $(\mathrm{ACHC})$ residue. We demonstrate that a direct correlation exists between $\beta$-peptide hydrophobicity, as measured by RP-HPLC retention times, and planktonic antifungal activity against multiple clinical 
strains of $C$. albicans and against $C$. glabrata, $C$. parapsilosis and C. tropicalis. The mechanism of action of these $\beta$-peptides is thought to involve membrane disruption [30], and here we demonstrate that the activity of the $\beta$-peptide was independent of the presence of the cell wall in $C$. albicans. Our results indicate that $\beta$-peptide hydrophobicity has little effect on disruption of existing Candida spp. biofilms. However, $\beta$-peptides prevented the formation of biofilms in a hydrophobicity-dependent manner. Taken together, our results demonstrate that globally amphiphilic 14-helical $\beta$-peptides exhibit activity against the most prevalent fungal pathogens and prevent the formation of biofilms by these organisms, suggesting that these $\beta$-peptides have promise as antifungal agents.

\section{Results}

\subsection{Design and Synthesis of 14-Helical $\beta$-Peptides}

We designed and synthesized a set of sixteen 14-helical $\beta$-peptides, 1-16, (Figure 1, Table 1) that are 9 or $10 \beta$-amino acid residues long and possess a net charge of +4 . Based on our previous work demonstrating the importance of amphiphilicity and helix stability in $\beta$-peptide antifungal activity [29-31], all $\beta$-peptides used in this study were designed to be globally amphiphilic and contained approximately three residues per helical turn with at least one helix-stabilizing ACHC residue in every turn. To elucidate $\beta$-peptide structure-function relationships, we changed the structures of the peptide by varying: (i) the absence (1-8) or presence (9-16) of an N-termimal $\beta^{3}$-hTyr residue, (Figure 1, Table 1, X), (ii) the hydrophobic residue (Figure 1, Table 1, $\mathrm{R}_{2}$ ) as $\beta^{3}$-hAla, $\beta^{3}$-Et, $\beta^{3}$-hVal, ACHC, or $\beta^{3}$-hPhe, and (iii) the cationic residue of the helical repeat to be either $\beta^{3}$-hLys or $\beta^{3}$-hArg (Figure 1, Table 1 , $\mathrm{R}_{3}$ ). These structural variations also affected the $\beta$-peptide hydrophobicity as measured by RP-HPLC (Table1).

$\beta$-peptides were produced by microwave-assisted Fmoc synthesis at 20-40 $\mu$ mol scales and purified by RP-HPLC using a C18 column. MALDI mass spectrometry was used to validate the mass of each peptide as described previously [31]. Retention times determined by C18 RP-HPLC were used as a measure of the relative hydrophobicity of the $\beta$-peptides (Table 1). This approach has been used previously by our group and others to assess the relative hydrophobicity of different peptide structures $[31,40,41]$. Preliminary antifungal activity and mammalian toxicity evaluation were reported previously for $\beta$-peptides 1-16 as planktonic MIC against $C$. albicans and percent hemolysis at the MIC, respectively [31]. Concentrations of $\beta$-peptide resulting in 50\% hemolysis $\left(\mathrm{HC}_{50}\right)$ for $\beta$-peptides $\mathbf{1}-\mathbf{1 6}$ are also provided in Table $\mathrm{S} 1$.

\subsection{Planktonic Antifungal Activity of $\beta$-Peptide Is a Function of Hydrophobicity in Multiple C. albicans Strains}

Antifungal activity of the $\beta$-peptides against planktonic $C$. albicans was measured by quantifying the minimum inhibitory concentration (MIC) of the peptides according to a modified version of the protocol prescribed by the Clinical Laboratory Standards Institute (CLSI). We evaluated the planktonic antifungal activities of peptides 1-8 against three different $C$. albicans clinical isolates: SC5314, ATCC 90028, and $\mathrm{K} 1$. The K1 strain, isolated from a systemic Candida infection, forms dense biofilms and is also fluconazole-resistant [42-44]. Table 2 shows the RP-HPLC retention times, as a measure of hydrophobicity, and the MICs of the $\beta$-peptides against the three different clinical strains. The 
corresponding quantitative XTT measures of $C$. albicans metabolic activity as a function of $\beta$-peptide concentration are provided in Figure S1. MICs of the $\beta$-peptides varied from $4 \mu \mathrm{g} / \mathrm{mL}$ to greater than $128 \mu \mathrm{g} / \mathrm{mL}$, the highest concentration of each peptide tested. We observed very little to no variation in the MIC values across different $C$. albicans strains for all the $\beta$-peptides. Further, an inverse correlation existed between the HPLC retention times of the $\beta$-peptides and their MICs against all C. albicans strains tested, with $\beta$-peptide 8 being the most hydrophobic and active, followed by $\beta$-peptides 5 and 4 .

A

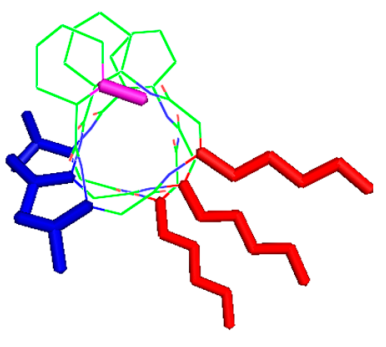

B

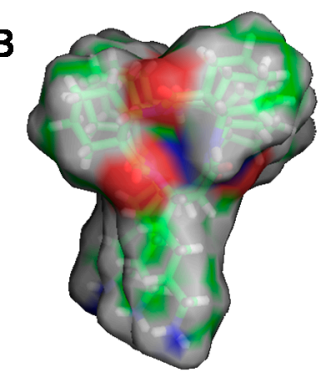

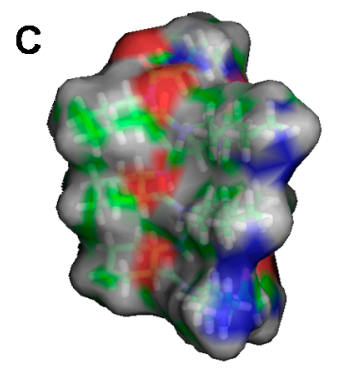

D
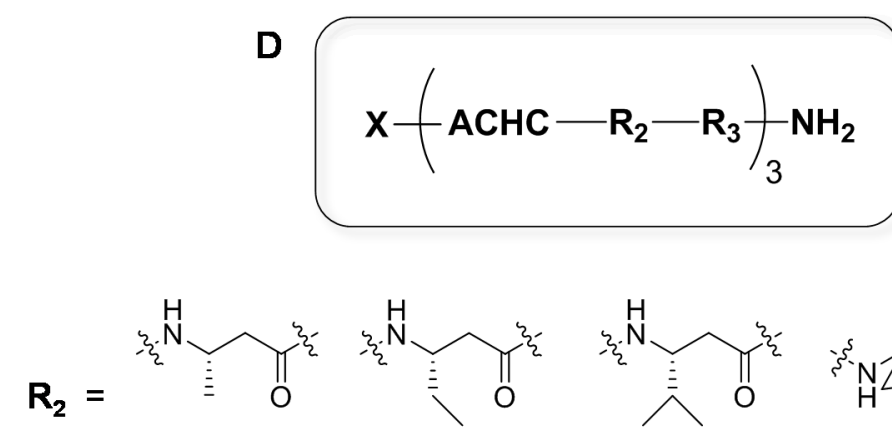<smiles>[Y]C(=O)CC(C)N</smiles>

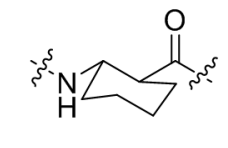<smiles></smiles>

$\beta^{3}$-hAla

$\beta^{3}$-Et

$\beta^{3}$-hVal

ACHC

$\beta^{3}$-hPhe

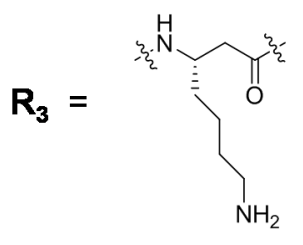

$\beta^{3}$-hLys<smiles>CC(N)CCCNC(=N)N</smiles>

$\beta^{3}$-hArg

$$
\mathbf{X}=\mathrm{\xi}^{-\mathrm{H}}
$$

$\beta^{3}$-hTyr

Figure 1. 14-Helical $\beta$-peptide design and chemical structures. 3D structures (A, B and $\mathbf{C})$ were generated based on available crystal structure data and then geometry was optimized using Gaussian 03 at the B3LYP/6-31G level. (A) Stick view of $\beta$-peptide 4. The N-terminus (pink), hydrophobic side chain (blue), and cationic side chain (red) are indicated in color. (B, C) Surface views of $\beta$-peptide 4. Surface colors represent atom type H (gray), O (red), and $\mathrm{N}$ (blue). (D) Chemical structures of $\beta$-peptides containing a helix-stabilizing ACHC residue and the $\mathrm{N}$-terminus $(\mathrm{X})$, hydrophobic $\left(\mathrm{R}_{2}\right)$, and cationic residues $\left(\mathrm{R}_{3}\right)$ were altered as indicated to vary peptide hydrophobicity. 
Table 1. Sequence and RP-HPLC retention times of 14-helical $\beta$-peptides, 1-16, used in this study.

\begin{tabular}{|c|c|c|c|c|}
\hline Peptide \# & $\mathrm{N}$ Terminus ${ }^{\mathrm{a}}(\mathrm{X})$ & Hydrophobic Residue a (R2) & Cationic Residue $^{\text {a }}$ (R3) & $\begin{array}{l}\text { Hydrophobicity (HPLC } \\
\text { Retention Time, min) } \\
\end{array}$ \\
\hline 1 & $\mathrm{H}$ & $\beta 3$-hAla & $\beta 3$-hLys & $19.3 \pm 0.1$ \\
\hline 2 & $\mathrm{H}$ & $\beta 3-E t$ & $\beta 3$-hLys & $22.5 \pm 0.2$ \\
\hline 3 & $\mathrm{H}$ & $\beta 3-E t$ & $\beta 3-\mathrm{hArg}$ & $23.2 \pm 0.1$ \\
\hline 4 & $\mathrm{H}$ & $\beta 3-\mathrm{hVal}$ & $\beta 3$-hLys & $24.5 \pm 0.2$ \\
\hline 5 & $\mathrm{H}$ & $\beta 3-\mathrm{hVal}$ & $\beta 3$-hArg & $25.4 \pm 0.1$ \\
\hline 6 & $\mathrm{H}$ & $\mathrm{ACHC}$ & $\beta 3$-hLys & $23.1 \pm 0.2$ \\
\hline 7 & $\mathrm{H}$ & $\mathrm{ACHC}$ & $\beta 3$-hArg & $23.8 \pm 0.1$ \\
\hline 8 & $\mathrm{H}$ & $\beta 3$-hPhe & $\beta 3$-hLys & $26.2 \pm 0.2$ \\
\hline 9 & $\beta 3$-hTyr & $\beta 3$-hAla & $\beta 3$-hLys & $20.4 \pm 0.2$ \\
\hline 10 & $\beta 3$-hTyr & $\beta 3-\mathrm{Et}$ & $\beta 3$-hLys & $23.5 \pm 0.1$ \\
\hline 11 & $\beta 3$-hTyr & $\beta 3$-Et & $\beta 3$-hArg & $24.2 \pm 0.1$ \\
\hline 12 & $\beta 3$-hTyr & $\beta 3-\mathrm{hVal}$ & $\beta 3$-hLys & $25.7 \pm 0.1$ \\
\hline 13 & $\beta 3$-hTyr & $\beta 3-\mathrm{hVal}$ & $\beta 3$-hArg & $26.5 \pm 0.2$ \\
\hline 14 & $\beta 3$-hTyr & $\mathrm{ACHC}$ & ß3-hLys & $24.0 \pm 0.2$ \\
\hline 15 & $\beta 3$-hTyr & $\mathrm{ACHC}$ & $\beta 3$-hArg & $24.6 \pm 0.2$ \\
\hline 16 & $\beta 3$-hTyr & $\beta 3$-hPhe & $\beta 3$-hLys & $27.4 \pm 0.2$ \\
\hline
\end{tabular}

${ }^{a}$ All three-letter amino acid codes refer to $\beta^{3}$-homoamino acids that have the same side chain as the corresponding $\alpha$-amino acids. $\beta^{3}$-Et refers to an ethyl side chain in the $\beta^{3}$ position and ACHC refers to trans-2-aminocyclohexanecarboxylic acid; b Error denotes standard deviation of triplicate experimental measurements.

Table 2. Minimum inhibitory concentrations (MICs) of peptides $\mathbf{1}-\mathbf{8}$ against $C$. albicans clinical isolates.

\begin{tabular}{ccccc}
\hline \multirow{2}{*}{ Peptide \# } & RT $^{\text {a }}(\mathbf{m i n})$ & \multicolumn{3}{c}{ MIC $^{\mathbf{b}}(\boldsymbol{\mu g} / \mathbf{m L})$} \\
\cline { 3 - 5 } $\mathbf{A T C C 9 0 0 2 8}$ & $\mathbf{K 1}$ & $\mathbf{S C 5 3 1 4}$ \\
\hline $\mathbf{2}$ & 19.3 & $>128$ & $>128$ & $>128$ \\
$\mathbf{6}$ & 22.5 & 64 & 64 & 64 \\
$\mathbf{3}$ & 23.1 & 32 & 32 & 16 \\
$\mathbf{7}$ & 23.2 & 32 & 32 & 32 \\
$\mathbf{4}$ & 23.8 & 32 & 16 & 16 \\
$\mathbf{5}$ & 24.5 & 16 & 16 & 8 \\
$\mathbf{8}$ & 25.4 & 16 & 8 & 8 \\
\hline
\end{tabular}

${ }^{a}$ The average value obtained from three independent analytical RP-HPLC measurements; ${ }^{\mathrm{b}}$ MICs were determined by taking the average of three experiments of three replicates each. C. albicans cells $\left(10^{3}\right.$ cells $\left./ \mathrm{mL}\right)$ were incubated with $\beta$-peptides for $48 \mathrm{~h}$ and $\beta$-peptide susceptibility was assessed using an XTT reduction assay to compare the absorbance at $490 \mathrm{~nm}$ for $\beta$-peptide-treated samples and untreated samples. 
2.3. $\beta$-Peptides Kill Planktonic C. glabrata, C. parapsilosis and C. tropicalis Cells in a Hydrophobicity-Dependent Manner

Relatively few AMPs have been investigated for their activity against Candida species other than C. albicans [45-47]. We hypothesized that because of their membrane disruption-based mechanism of antifungal activity [30,48,49], $\beta$-peptides might also be active against other Candida pathogens. We therefore performed planktonic susceptibility experiments against $C$. glabrata, C. parapsilosis and C. tropicalis according to a modified protocol of CLSI, with a quantitative XTT end point (Figures 2A and S2), similar to susceptibility experiments performed on C. albicans described above. The set of $\beta$-peptides 1-8 exhibited a wide range of MICs against all three species, from $8 \mu \mathrm{g} / \mathrm{mL}$ to greater than $128 \mu \mathrm{g} / \mathrm{mL}$ against $C$. glabrata, from $4 \mu \mathrm{g} / \mathrm{mL}$ to greater than $128 \mu \mathrm{g} / \mathrm{mL}$ against $C$. parapsilosis, and from $2 \mu \mathrm{g} / \mathrm{mL}$ to $64 \mu \mathrm{g} / \mathrm{mL}$ against $C$. tropicalis (Figure 2A, Table S2). In general, for all $\beta$-peptides tested, $C$. tropicalis was most susceptible to the peptide with comparatively lower MICs and C. glabrata was the least susceptible to the $\beta$-peptide with relatively higher MICs.

A
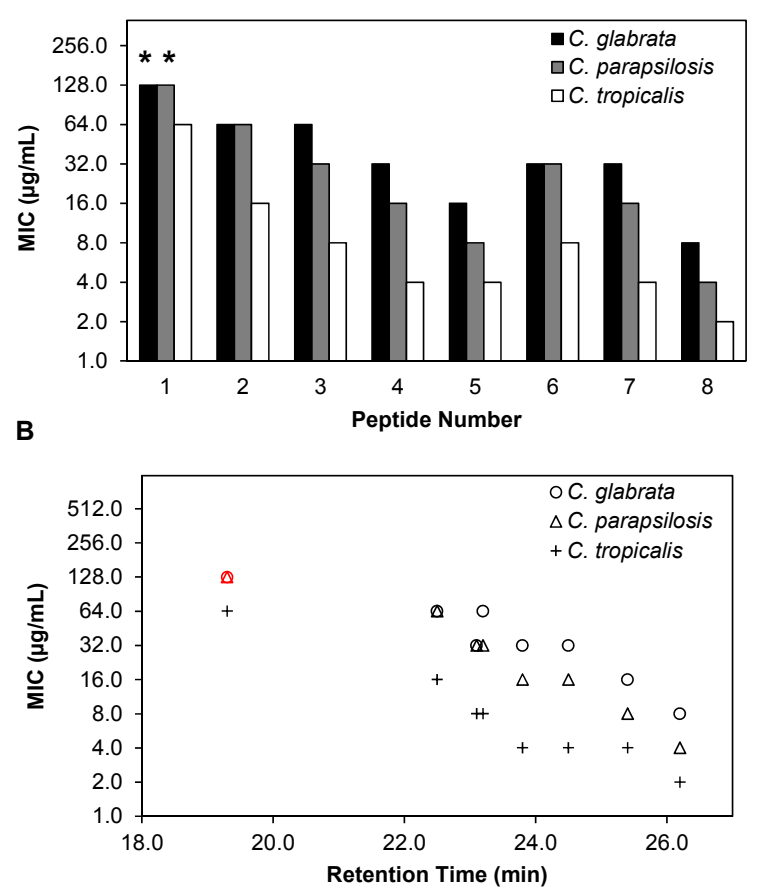

Figure 2. $\beta$-peptides are effective against planktonic C. glabrata, C. parapsilosis, and C. tropicalis and antifungal activities correlate with $\beta$-peptide RP-HPLC retention times. (A) Minimum inhibitory concentrations (MICs) of peptides $\mathbf{1}-\mathbf{8}$ against $C$. glabrata (black bars), C. parapsilosis (grey bars), and C. tropicalis (white bars). MICs were determined by incubating $C$. glabrata, $C$. parapsilosis, and $C$. tropicalis cells $\left(10^{3}\right.$ cells $\left./ \mathrm{mL}\right)$ with $\beta$-peptides for $48 \mathrm{~h}$ and $\beta$-peptide susceptibility was assessed using an XTT reduction assay to compare the absorbance at $490 \mathrm{~nm}$ for $\beta$-peptide-treated samples and untreated samples. (B) Plot of planktonic MIC versus RP-HPLC retention times of peptides 1-8 against C. glabrata (circles), C. parapsilosis (triangles), and C. tropicalis (plus signs). Experiments were performed on at least two independent days with three replicates each. Asterisks $\left({ }^{*}\right)$ and red symbols indicate that MIC was $>128 \mu \mathrm{g} / \mathrm{mL}$, the highest concentration of peptide assayed. 
We next investigated the influence of $\beta$-peptide hydrophobicity on activity against $C$. glabrata, C. parapsilosis and C. tropicalis. We observed a similar inverse relationship between the hydrophobicity of the $\beta$-peptide and the MIC against all three pathogens (Figure 2B). Overall, $\beta$-peptide 8, the most hydrophobic $\beta$-peptide tested, was the most active against all Candida species tested, while $\beta$-peptide 1, the least hydrophobic, was the least active against all species.

To corroborate the MIC data based on XTT measurements, we performed a fluorescence assay to visualize the colocalization of $\beta$-peptide with dead cells in different Candida spp. We selected peptide 4, which had a relatively low MIC against all Candida spp., and is also specific i.e., non-toxic to mammalian cells with a relatively high $\mathrm{HC}_{50}$ of $161 \mu \mathrm{g} / \mathrm{mL}$ (Tables S1and S2) and labeled it with coumarin (peptide $4_{\mathrm{FL}}$ ) as described previously for monitoring $\beta$-peptide localization on $C$. albicans cells [30]. We verified that the addition of the fluorescent label to the peptide did not substantially affect the MIC of the $\beta$-peptide (Table S3). In all Candida species at concentrations up to 4 -fold below the MIC, very few dead cells were detected by PI staining (Figures 3 and S3). At the MIC and at higher concentrations of the $\beta$-peptide, we observed substantial cell death by PI staining, with the labeled $\beta$-peptide associated with the cells (Figures 3 and S3).

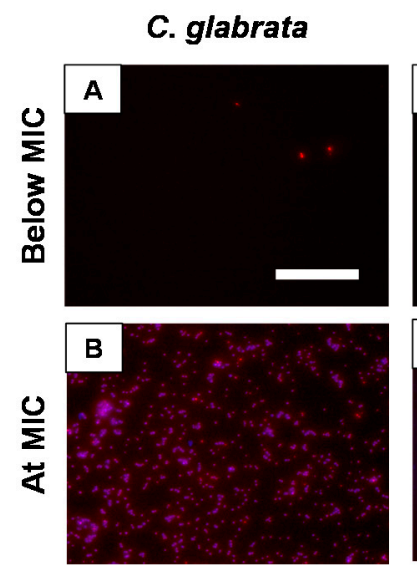

\section{C. parapsilosis}
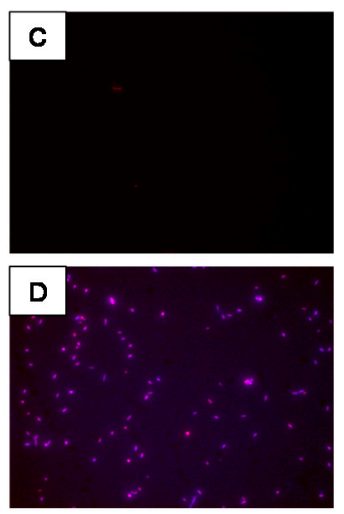

\section{C. tropicalis}

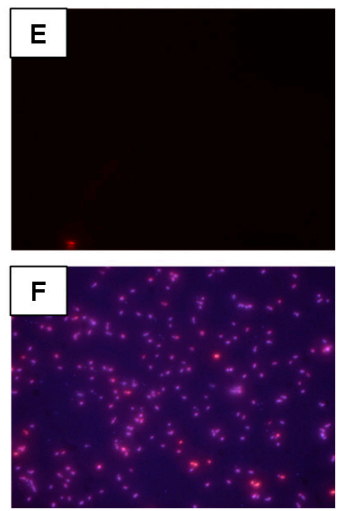

Figure 3. Fluorescence micrographs of C. glabrata (A, B), C. parapsilosis (C, D), and C. tropicalis $(\mathbf{E}, \mathbf{F})$ treated with peptide $4_{\mathrm{FL}}$. Cells $\left(10^{5} \mathrm{cells} / \mathrm{mL}\right)$ were treated with peptide $\mathbf{4}_{\mathrm{FL}}$ (blue) at a concentration 4-fold below the MIC (A, C, E) and at the MIC (B, D, F) for 3.5 h. Cells were stained with PI to identify dead cells (red). Scale bar $=100 \mu \mathrm{m}$.

\subsection{The Cell Wall Does Not Significantly Affect the Activity of $\beta$-Peptides against $C$. albicans}

The mechanism of action of $\beta$-peptides against $C$. albicans is understood to be through the disruption of the cell membrane [30]. Here, we evaluated if the $C$. albicans cell wall affects the activity of the $\beta$-peptides. We enzymatically degraded C. albicans cell walls to generate spheroplasts (SPs). We confirmed the generation of SPs using visual observation by microscopy (Figure 4A-D) and by evaluating the susceptibility of SPs to increasing concentrations of SDS. SPs were more susceptible than yeast cells to SDS, with complete SP disruption observed at $0.5 \%$ SDS while yeast cells remained intact (Figure 4E,F). We then performed planktonic susceptibility assays of freshly prepared SPs and yeasts, in the presence of varying concentrations of $\beta$-peptide to evaluate the MIC of the peptide against SP and 
yeast, to elucidate the influence of the cell wall on MIC. We observed no significant differences in MIC values against either SPs or yeast for active $\beta$-peptides $\mathbf{4}$ and $\mathbf{5}$ and for inactive $\beta$-peptide $\mathbf{1}$ (Figure 4G-J).
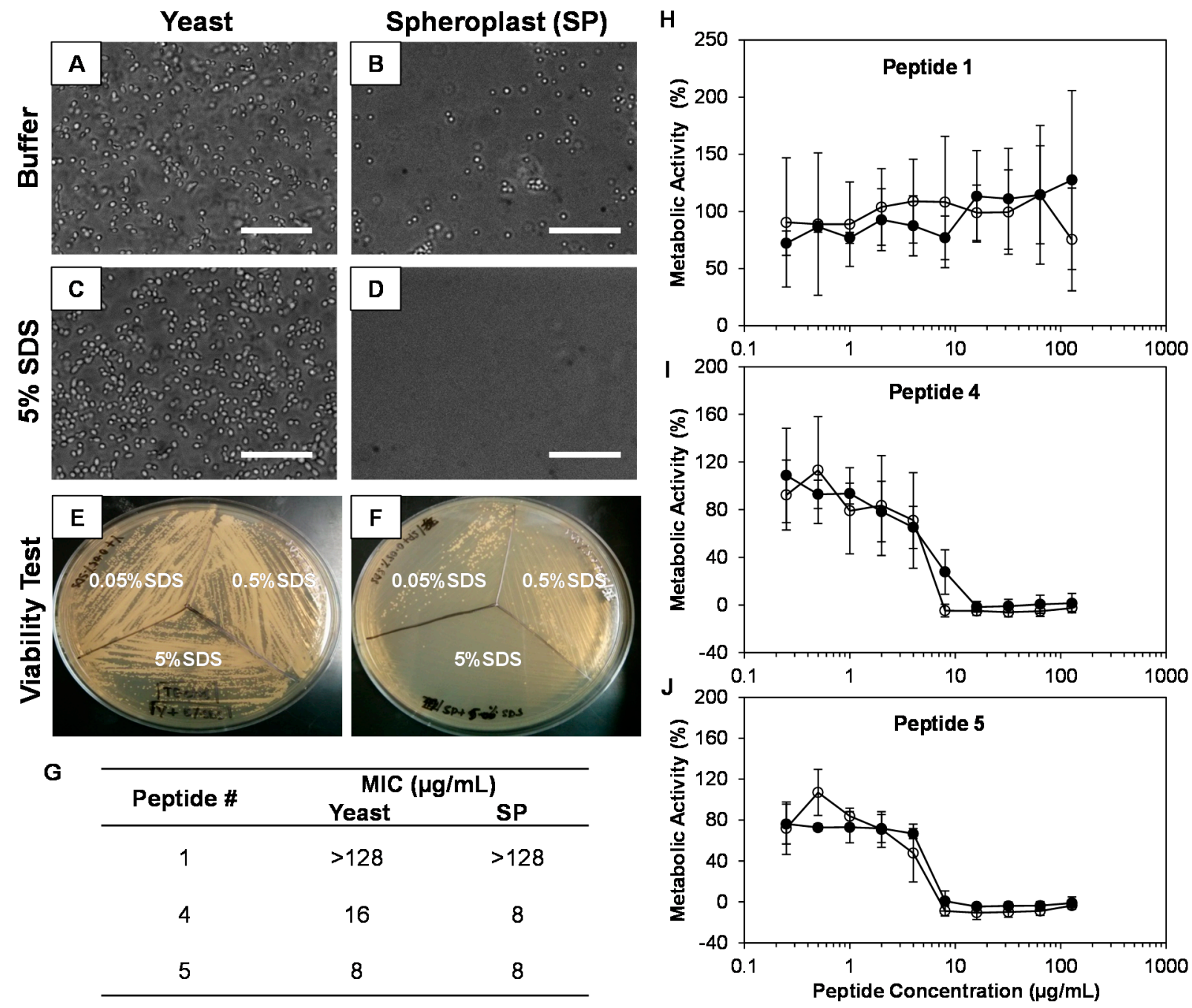

Figure 4. $\beta$-peptide activity against $C$. albicans spheroplasts (SPs). (A-D) Phase contrast microscopy of overnight cultures of yeast $(\mathbf{A}, \mathbf{C})$ or after cell wall removal to yield SPs $(\mathbf{B}, \mathbf{D})$ in buffer solution (A, B) and in the presence of 5\% SDS (C, D). Scale bars $=50 \mu \mathrm{m}$. Agar plates showing viability of yeast $(\mathbf{E})$ and spheroplasts $(\mathbf{F})$ in the presence of increasing concentrations of SDS. (G) Comparison of the MICs of C. albicans yeast and SPs against $\beta$-peptides. (H-J) Plots of concentration-dependent growth inhibition of $C$. albicans yeast (black circles) and SPs (white circles) by $\beta$-peptides 1, 4 and 5. C. albicans yeast cells and SPs $\left(10^{3}\right.$ cells $\left./ \mathrm{mL}\right)$ were incubated with $\beta$-peptides for $48 \mathrm{~h}$ and $\beta$-peptide susceptibility was assessed using an XTT assay to compare the absorbance at $490 \mathrm{~nm}$ for $\beta$-peptide-treated samples and untreated samples. Data points are the average of two independent experiments of three replicates each and error bars denote standard deviation.

\section{5. $\beta$-Peptide Hydrophobicity Does Not Affect Activity against Existing C. albicans Biofilms}

We next investigated whether $\beta$-peptides were effective against biofilms formed for $48 \mathrm{~h}$ in the absence of $\beta$-peptide, and to what extent hydrophobicity of the $\beta$-peptide affected the MIC against these 
biofilms. We evaluated two different series of peptides of increasing hydrophobicity, peptides 1-8 and 9-16, that were synthesized without and with an N-termimal $\beta^{3}$-hTyr residue (Table 1, Figures 5A and S4). MICs against existing biofilms were defined as the lowest concentration of peptide needed to reduce metabolic activity, measured by an XTT assay, of the cells in biofilms to less than $10 \%$ compared to control untreated biofilms. We observed that the MICs of all $\beta$-peptides against biofilms were in the range of 128 to $>512 \mu \mathrm{g} / \mathrm{mL}$ and in many cases were much higher than corresponding planktonic MICs (Table 2, Table S4). Increasing the hydrophobicity of the $\beta$-peptide did not decrease the MIC against pre-formed C. albicans biofilms (Figure 5B). However, $\beta$-peptides 9-16 containing the N-terminal $\beta^{3}$-hTyr residue had higher MICs compared to peptides $\mathbf{1 - 8}$, which did not contain the $\beta^{3}$-hTyr residue (Figure 5B).

\subsection{Hydrophobicity of $\beta$-Peptide Affects Prevention of C. albicans Biofilm Formation}

While $\beta$-peptides exhibited low activities against existing biofilms, the ability to prevent biofilm formation would be of practical utility. To determine if our $\beta$-peptides could inhibit biofilm formation, we quantified the formation of $C$. albicans biofilms in the presence and absence of $\beta$-peptides 1-16. 1000 -Fold higher cell concentrations compared to planktonic susceptibility experiments were added to 2 -fold dilutions of $\beta$-peptide and incubated at $37^{\circ} \mathrm{C}$ to form biofilms for $48 \mathrm{~h}$. XTT was used to measure the metabolic activities of the cells and determine the MIC of the peptide against biofilm formation, defined as the lowest concentration of the peptide that resulted in metabolic activity of $10 \%$ or less compared to untreated control cells (Figure S4). $\beta$-Peptides exhibited MICs in the range of 4-512 $\mu \mathrm{g} / \mathrm{mL}$ (Table S4) and all $\beta$-peptides that were active against planktonic $C$. albicans were also effective in preventing biofilm formation to similar extents (Figure 5C and Table 2, S4). Additionally, we observed $\beta$-peptide hydrophobicity to be an important design parameter for preventing biofilm formation, with $\beta$-peptides having greater hydrophobicity being more effective in preventing $C$. albicans biofilm formation (Figure 5D). The correlation between hydrophobicity and anti-biofilm-forming activity occurred independent of other structural features of the $\beta$-peptides, such as the identity of the cationic residue ( $\beta^{3}$-hLys or $\beta^{3}$-hArg) and the $\mathrm{N}$-terminus (with or without $\beta^{3}$-hTyr).

\section{7. $\beta$-Peptides Prevent C. glabrata, C. parapsilosis and C. tropicalis Biofilm Formation}

C. glabrata, C. parapsilosis, and C. tropicalis are all species capable of forming biofilms to varying extents and biofilm formation is a virulence factor responsible for their pathogenicity [32,37,38]. We therefore also evaluated whether $\beta$-peptides were effective in disrupting or preventing biofilms of these species. We selected $\beta$-peptides 4, 5 and $\mathbf{8}$ (that were active) and $\beta$-peptide $\mathbf{1}$ (that was inactive) against planktonic cells, and evaluated the MIC of these peptides against existing C. glabrata, C. parapsilosis, and C. tropicalis biofilms (Figure S5). As observed in C. albicans experiments, all $\beta$-peptides exhibited substantially greater MICs against pre-formed biofilms compared to planktonic cells (Table S5). Additionally, there was not a correlation between hydrophobicity of the $\beta$-peptide and MIC observed against biofilms (Figure 6A, B). However, we found that the MICs of $\beta$-peptide required in preventing biofilms were similar to the planktonic MICs for all $\beta$-peptides and species tested (Figures 6C, S6 and 2A). Further, the MICs of the $\beta$-peptides observed against all the Candida species were inversely correlated to the hydrophobicity of the $\beta$-peptide (Figure 6D). 
A

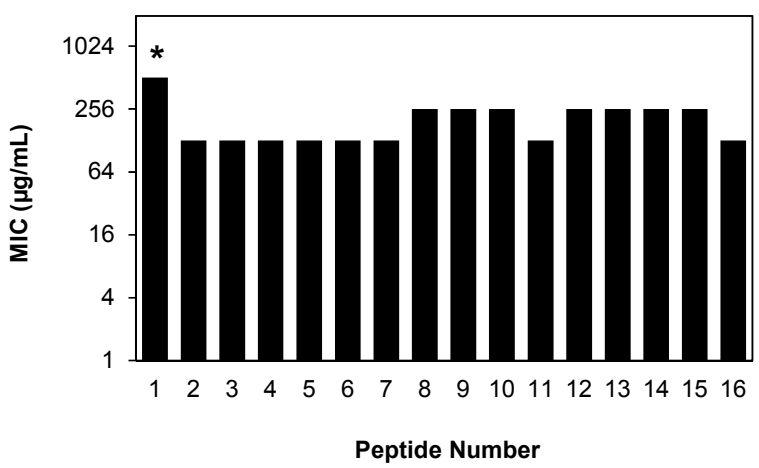

C

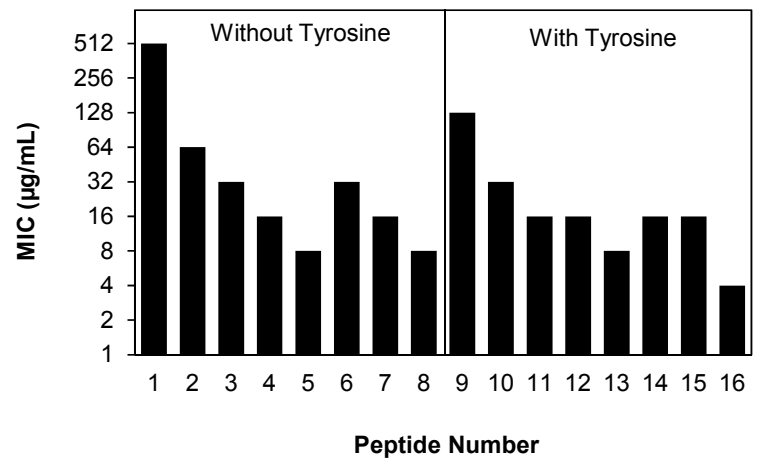

B

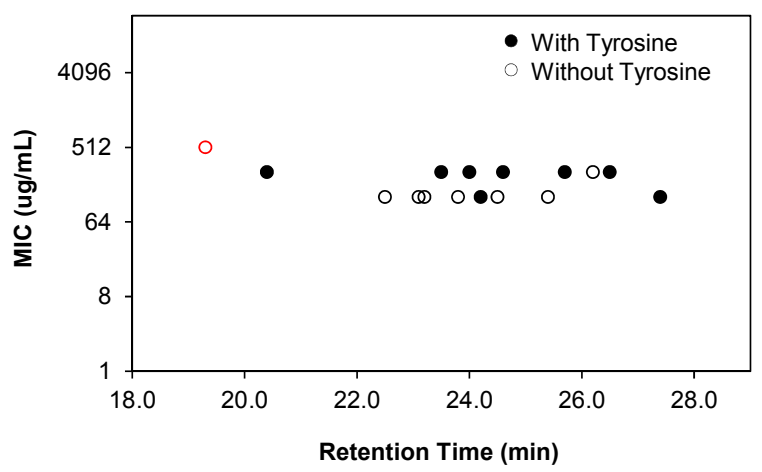

D

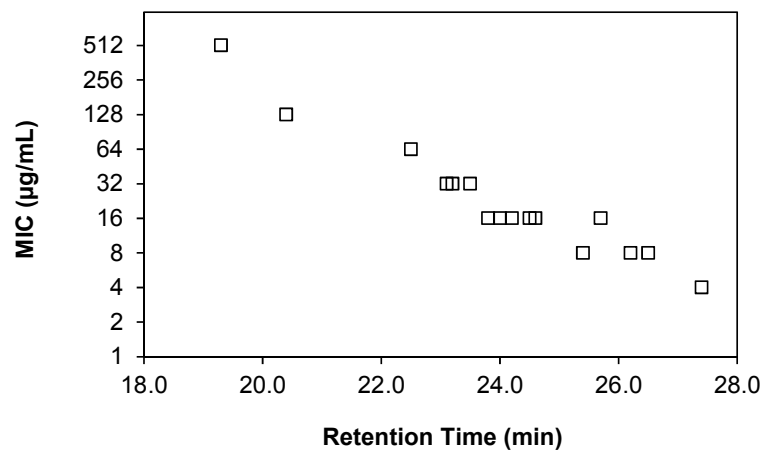

Figure 5. Antifungal activities of $\beta$-peptides against $C$. albicans biofilms. (A) Mature biofilms were formed by incubating C. albicans cells $\left(10^{6}\right.$ cells $\left./ \mathrm{mL}\right)$ for $48 \mathrm{~h}$. Planktonic cells were removed, biofilms were washed, and 2-fold dilutions of $\beta$-peptides were added and incubated for an additional $48 \mathrm{~h}$. $\beta$-peptide MICs were quantified using an XTT assay to compare the absorbance at $490 \mathrm{~nm}$ for $\beta$-peptide-treated samples and untreated samples. (B) Plot of biofilm MICs versus RP-HPLC retention times of peptides 1-16 against C. albicans for peptides without (white circles, peptides 1-8) and with (black circles, peptides 9-16) an N-terminal $\beta^{3}$-hTyr residue. (C) MICs against $C$. albicans biofilm formation were determined by incubating $C$. albicans cells $\left(10^{6}\right.$ cells $\left./ \mathrm{mL}\right)$ with 2 -fold dilutions of $\beta$-peptides for $48 \mathrm{~h}$. Planktonic cells were removed, biofilms were washed and $\beta$-peptide susceptibility was assessed using an XTT assay to compare the absorbance at $490 \mathrm{~nm}$ for $\beta$-peptide-treated samples and untreated samples. (D) Plot of MICs to prevent biofilm formation versus RP-HPLC retention times of the peptides 1-16 against $C$. albicans. Experiments were performed on at least two independent days with three replicates each. Asterisks (*) and red symbols indicate that MIC was $>512 \mu \mathrm{g} / \mathrm{mL}$, the highest concentration of peptide assayed. 


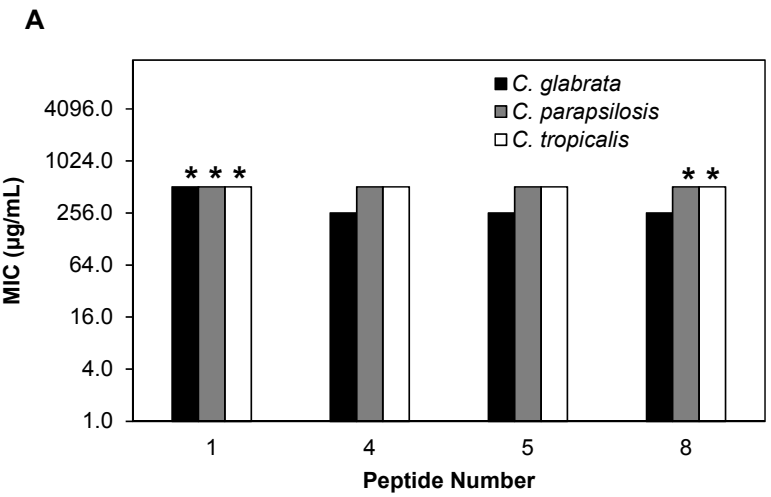

B
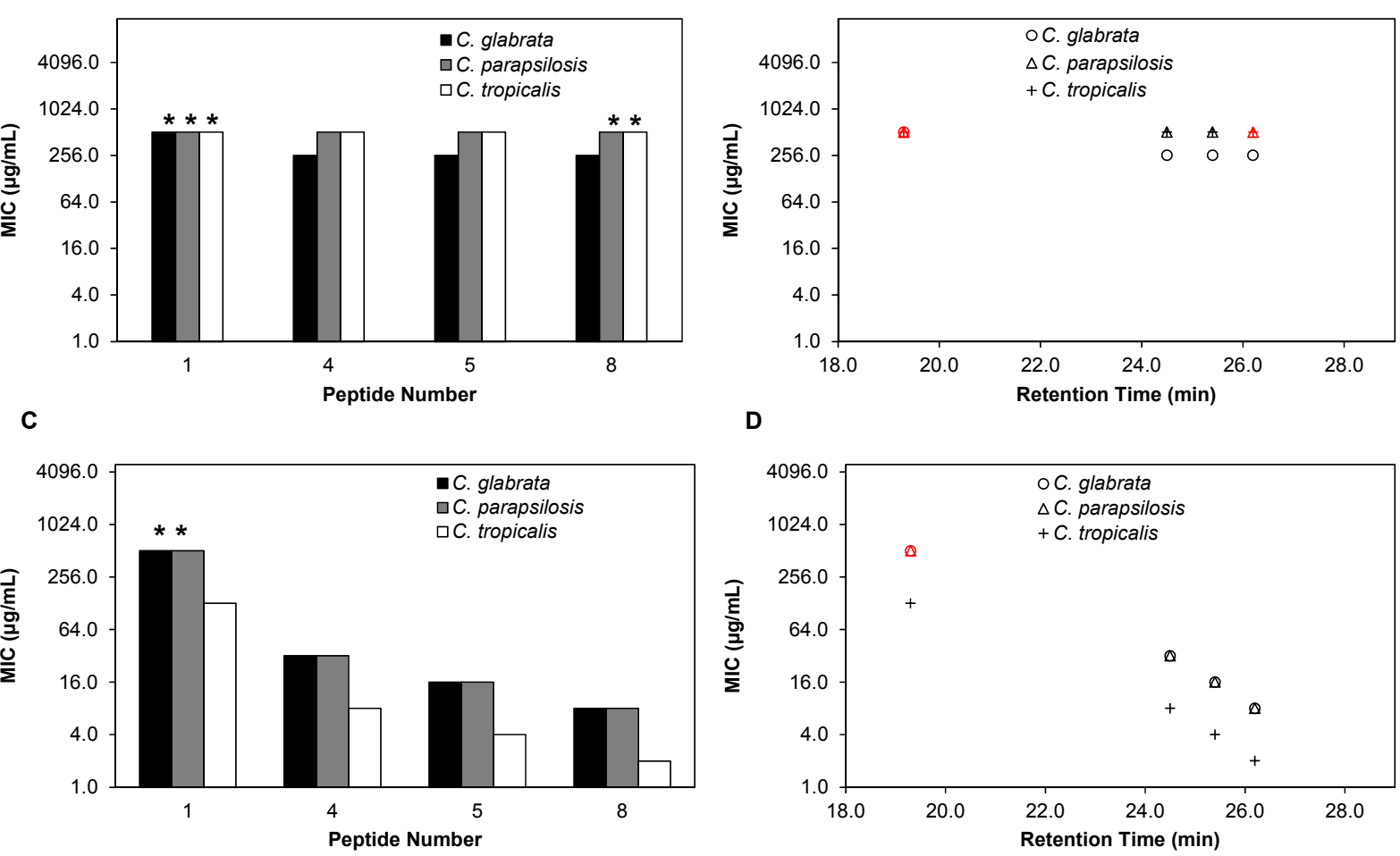

D

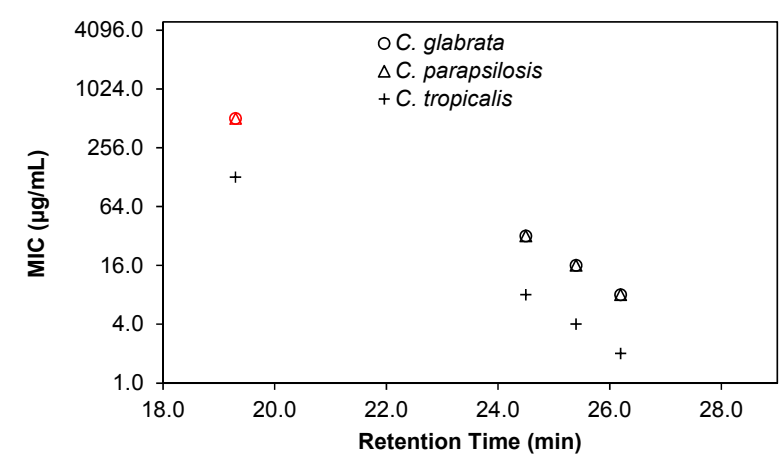

Figure 6. Antifungal activities of $\beta$-peptides against $C$. glabrata, $C$. parapsilosis and C. tropicalis biofilms. (A) Mature biofilms were formed by incubating C. glabrata (black bars), C. parapsilosis (grey bars), and C. tropicalis (white bars) cells $\left(10^{6}\right.$ cells $/ \mathrm{mL}$ ) for $48 \mathrm{~h}$. Planktonic cells were removed, biofilms were washed, and 2-fold dilutions of $\beta$-peptides were added and incubated for an additional $48 \mathrm{~h}$. $\beta$-Peptide MICs were quantified using an XTT assay to compare the absorbance at $490 \mathrm{~nm}$ for $\beta$-peptide-treated samples and untreated samples. (B) Plot of biofilm MICs versus RP-HPLC retention times of $\beta$-peptides 1, 4, 5 and 8 against $C$. glabrata (circles), C. parapsilosis (triangles), and C. tropicalis (plus signs). (C) MICs against C. glabrata (black bars), C. parapsilosis (grey bars), and C. tropicalis (white bars) biofilm formation were determined by incubating cells $\left(10^{6}\right.$ cells $\left./ \mathrm{mL}\right)$ with 2 -fold dilutions of $\beta$-peptides for $48 \mathrm{~h}$. Planktonic cells were removed, biofilms were washed, and $\beta$-peptide susceptibility was assessed using an XTT assay to compare the absorbance at $490 \mathrm{~nm}$ for $\beta$-peptide-treated samples and untreated samples. (D) Plot of MICs for inhibition of biofilm formation versus RP-HPLC retention times of the $\beta$-peptides 1, 4, 5 and 8 against C. glabrata (circles), C. parapsilosis (triangles), and C. tropicalis (plus signs). Experiments were performed on at least two independent days with three replicates each. Asterisks (*) and red symbols indicate that MIC was $>512 \mu \mathrm{g} / \mathrm{mL}$, the highest concentration of peptide assayed.

\section{Discussion}

For AMPs and their structural mimetics to realize their potentials as antimicrobial therapeutics, prevention of biofilm formation is an important criterion. 14-Helical $\beta$-peptides form well-characterized secondary structures and can be designed to possess desired properties by sequence-specific 
incorporation of $\beta$-amino acid residues [50-52]. Prior studies have demonstrated that globally-amphiphilic $\beta$-peptides can exhibit specific activity against $C$. albicans [30]. Here, we evaluated the antifungal activity of 14-helical $\beta$-peptides against multiple $C$. albicans clinical isolates, including a drug-resistant strain, and against other pathogenic Candida spp. We further evaluated the effect of $\beta$-peptides on biofilms of these species and identified a correlation between $\beta$-peptide hydrophobicity and antifungal activity against both planktonic cells and during prevention of biofilm formation.

Planktonic susceptibility experiments against three $C$. albicans clinical isolates indicated that $\beta$-peptides are effective against multiple strains and that hydrophobicity correlates with $\beta$-peptide activity against $C$. albicans. It is particularly noteworthy that even though the K1 strain is fluconazole-resistant, it is still susceptible to the action of $\beta$-peptides, indicating that the membrane-disruption mechanism of action of these $\beta$-peptides is effective even against $C$. albicans strains that acquire resistance to traditional antifungal drugs. Although the mechanism of action of many AMPs in general, and $\beta$-peptides in particular, is thought to involve cell membrane disruption [30,48,49], there is limited understanding regarding the role that the cell wall plays. The cell wall has been suggested to be necessary for the activity of AMPs in certain cases and plays an important role in the capture and anchoring of peptides to the cell $[49,53,54]$. In other instances, the cell wall has been shown to decrease the activity of AMPs by sequestering the peptide and acting as a barrier to the translocation of peptide into the cell $[49,55]$. We observed that the planktonic MICs of both active and inactive $\beta$-peptides did not change upon removing the cell wall from $C$. albicans yeast indicating that the cell wall does not affect the antifungal action of $\beta$-peptides.

The hydrophobicity of both antimicrobial $\alpha$-peptides and 14-helical $\beta$-peptides has been shown to be important for antifungal activity against planktonic $C$. albicans cells, but studies indicate that AMPs that are active against planktonic cells need not necessarily be active against biofilm cells (and vice versa) $[31,40,41,56]$. We used a simplified in vitro biofilm model to study the effects of $\beta$-peptide in preventing the formation of and inhibiting existing biofilms of various Candida spp. Although in vitro biofilms develop and exist in a different context from those that occur in vivo, where shear force and continuous flux of material play important roles in biofilm development, in vitro static biofilms provide a good starting point to understand the effects of $\beta$-peptide on biofilms. Our results indicate that the antifungal MICs of 14-helical $\beta$-peptides against planktonic C. albicans (and in preventing biofilm formation) depend on the hydrophobicity of the $\beta$-peptide: more hydrophobic peptides exhibit greater antifungal activities, with lower MICs. However, the MICs of the $\beta$-peptides against existing biofilms were higher than those against planktonic cells or for inhibiting biofilm formation, and were also independent of $\beta$-peptide hydrophobicity. Mature $C$. albicans biofilms consist of communities of both yeast and hyphal cells encased in a three-dimensional extracellular matrix (ECM), whereas during the process of biofilm formation cells are mainly in the yeast form with little or no ECM [38,57]. We hypothesize that the higher MICs observed against biofilms could potentially be due to multiple reasons including (i) the increase in concentration of the cells in the biofilm [57], leading to peptide potentially being sequestered onto the cell membrane, thus depleting free peptide remaining in solution (however, it is noteworthy that all $\beta$-peptides have nearly the same MICs against planktonic cells and during inhibition of biofilm formation, even though the cell concentration was 1000 -fold higher in the latter experiment), (ii) differences in the phenotype and morphology of the cells present in the mature biofilm compared to planktonic cells [18] and their differential susceptibility to $\beta$-peptides, and (iii) biofilm 
ECM trapping the $\beta$-peptide and making them unavailable in sufficient amounts to lyse $C$. albicans cells. Studies have demonstrated that components of the ECM, including glycans, are capable of sequestering traditional antifungal drugs and are responsible for increased MICs [58]. Nevertheless, from a translational standpoint it is important to note that $\beta$-peptides remain active against biofilm formation and therefore have potential for prophylaxis and early-stage infection prevention.

Other Candida species, especially C. glabrata, C. parapsilosis, and C. tropicalis, have increasingly been observed as infectious agents in hospital settings and therefore there is a growing need to develop drugs or test existing drugs to combat them [33]. Some of the drugs used against $C$. albicans, including amphotericin B and fluconazole, are also used to treat C. glabrata, C. parapsilosis, and C. tropicalis infections [37]. However, few AMPs have been tested against these Candida species [37,45-47]. We found that 14 -helical $\beta$-peptides are also active against $C$. glabrata, $C$. parapsilosis, and $C$. tropicalis species to varying extents against planktonic cells and in preventing biofilm formation. Additionally, we observed that even at sub-MIC concentrations, the fungi were affected by the peptide and we observed stunted pseudohyphae and more rounded yeast, especially in C. tropicalis, similar to what has been previously reported for C. albicans [59] (Figure S3). Among planktonic cells, we observed that $C$. tropicalis was the most susceptible to $\beta$-peptides while $C$. glabrata was the least susceptible. C. glabrata is known to exhibit higher MICs against traditional antifungal drugs and against cationic antifungal peptides $[34,60]$. Here, differences in membrane composition may potentially explain the variation in susceptibility of each species to the $\beta$-peptides investigated here [61]. Despite C. glabrata being the most resistant to the planktonic antifungal activity of $\beta$-peptides, we observed that $C$. glabrata biofilms were more susceptible to $\beta$-peptides compared to $C$. parapsilosis and $C$. tropicalis biofilms. This is possibly due to the fact that $C$. glabrata form less robust biofilms in comparison to the other two Candida species [32]. The direct relationship between the hydrophobicity of $\beta$-peptide and its antifungal activity observed against planktonic $C$. albicans was also observed against planktonic C. glabrata, C. parapsilosis, and C. tropicalis.

\section{Experimental Section}

\subsection{Materials}

Fmoc- $\beta$-amino acids, including Fmoc-L- $\beta$-homoalanine, Fmoc-L- $\beta$-homovaline, Fmoc- $O$-tert-butylL- $\beta$-homotyrosine, $\quad N \beta$-Fmoc-N $\omega$-Boc-L- $\beta$-homolysine, $\quad$ and Fmoc- $N \omega-(2,2,5,7,8$-pentamethylchromane-6-sulfonyl)-L- $\beta$-homoarginine were purchased from Chem-Impex International, Inc. (Wood Dale, IL, USA) TentaGel S RAM Fmoc, HBTU ( $O$-(benzotriaole-1-yl)- $N, N, N^{\prime}, N^{\prime}$-tetramethyluronium hexafluorophosphate), and $\mathrm{HOBt} \cdot \mathrm{H}_{2} \mathrm{O}$ ( $N$-hydroxybenzotrizole monohydrate) were purchased from Advanced ChemTech. (Louisville, KY, USA) (S)-3-Aminopentanoic acid was purchased from Sigma-Aldrich (St Louis, MO, USA) for synthesis of Fmoc- $(S)$-3-aminopentanoic acid (Fmoc- $\beta^{3}$-Et-OH). RPMI 1640 powder (with L-glutamine and phenol red, without HEPES and sodium bicarbonate) and 2,3-bis-(2-methoxy-4-nitro-5-sulfophenyl)-2H-tetrazolium-5-carboxanilide (XTT) were purchased from Invitrogen (Grand Island, NY, USA). 3-( $N$-Morpholino) propanesulfonic acid (MOPS) and phosphate-buffered saline (PBS) liquid concentrate (10X) were purchased from Fisher 
Scientific (Pittsburgh, PA, USA). Zymolase was purchased from Zymo Research (Irvine, CA, USA). Menadione and melittin were purchased from Sigma-Aldrich.

\section{2. $\beta$-Peptide Synthesis}

$\beta$-peptides were synthesized using TentaGel (20-40 $\mu \mathrm{mol})$ microwave-assisted solid phase peptide synthesis procedures similar to those reported previously [62]. Briefly, the solution of Fmoc- $\beta$-amino acid, coupling reagent (HBTU, HOBt), and base (DIPEA) in DMF were mixed before coupling. Microwave (CEM Discover) irradiation methods were used for coupling of Fmoc- $\beta$-amino acid (600 W maximum power, $70{ }^{\circ} \mathrm{C}$, ramp $2 \mathrm{~min}$, hold $12 \mathrm{~min}$ ) and deprotection of Fmoc (600 W maximum power, $80^{\circ} \mathrm{C}$, ramp $2 \mathrm{~min}$, hold $6 \mathrm{~min}$ ). After each coupling and deprotection step, the resin was thoroughly washed with DMF and $\mathrm{CH}_{2} \mathrm{Cl}_{2}$, and then the peptide was cleaved from the resin by TFA containing $\mathrm{H}_{2} \mathrm{O}$ $(2.5 \%)$ and triisopropylsilane $(2.5 \%)$ for 1 to $2 \mathrm{~h}$. The crude product was purified by preparative RP-HPLC with a gradient of $25 \%-73 \% \mathrm{CH}_{3} \mathrm{CN}$ in water containing $0.1 \%$ TFA.

\subsection{Characterization of $\beta$-Peptide Hydrophobicity}

Hydrophobicity of 14-helical $\beta$-peptides was characterized by measuring retention times with an analytical RP-HPLC using a C18 column (Waters, X-bridge, column dimensions $4.6 \mathrm{~mm} \times 250 \mathrm{~mm}$, Milford, MA, USA). The $\beta$-peptide solutions $(0.5$ to $1 \mathrm{mg} / \mathrm{mL}, 50 \mu \mathrm{L})$ were injected into the HPLC at a flow rate of $1 \mathrm{~mL} /$ minute. Retention time was characterized in triplicate with a gradient of $20 \%-80 \%$ $\mathrm{CH}_{3} \mathrm{CN}$ in water containing $0.1 \%$ TFA over $5-35 \mathrm{~min}$.

\subsection{Yeast Strain and Culture Conditions}

C. albicans strains SC5314 and ATCC 90028 were purchased from ATCC. C. albicans K1, C. glabrata 5376, C. parapsilosis 5986 and C. tropicalis 98-234 are clinical isolates from invasive candidiasis [63] and were generously donated by the Andes group (University of Wisconsin-Madison). $\mathrm{K} 1$ is fluconazole resistant $[42,43]$. All strains were stored as a $50 \%$ glycerol stock at $-80{ }^{\circ} \mathrm{C}$ and grown in a liquid YPD media. For planktonic susceptibility testing, cells were grown on agar plates at $30{ }^{\circ} \mathrm{C}$ for $24 \mathrm{~h}$ and 2-3 colonies were used for the cell inoculum. For spheroplast formation and biofilm susceptibility testing assays, cells were grown overnight in YPD at $30{ }^{\circ} \mathrm{C}$. RPMI (with L-glutamine and phenol red buffered with 3-( $N$-morpholino) propanesulfonic acid and adjusted to $\mathrm{pH} 7.0)$ was the media used for all susceptibility tests. XTT solution for assessing metabolic activity was prepared at $0.5 \mathrm{~g} / \mathrm{L}$ in PBS with $3 \mu \mathrm{M}$ menadione in acetone and $\mathrm{pH}$ adjusted to 7.4.

\subsection{Planktonic Antifungal Susceptibility Testing}

The antifungal activities of the $\beta$-peptides against $C$. albicans, C. glabrata, C. parapsilosis, C. tropicalis cells were assayed in accordance to the guidelines for planktonic susceptibility testing provided by the Clinical and Laboratory Standards Institute, but with a modification to include a quantitative XTT cell metabolic activity end-point [30]. $100 \mu \mathrm{L}$ of two-fold serially diluted concentrations of $\beta$-peptides in RPMI were mixed with $100 \mu \mathrm{L}$ of a $C$. albicans strain SC5314, ATCC 90028, K1, C. glabrata 5376, C. parpsilosis 5986, C. tropicalis 98-234 cell suspensions adjusted to 
$1 \times 10^{3}-5 \times 10^{3}$ cells $/ \mathrm{mL}$ and the plates were incubated at $35^{\circ} \mathrm{C}$ for $48 \mathrm{~h}$. Cell only controls consisting of wells without $\beta$-peptide and media controls consisting of wells without both $\beta$-peptide and cells were included in the 96-well plate, for every $\beta$-peptide screened. After $48 \mathrm{~h}$, the MICs were recorded visually as the first well that had growth and by using an XTT metabolic assay.

\subsection{Fluorescence Imaging of Planktonic C. glabrata, C. parapsilosis and C. tropicalis}

To image the interaction of peptide $4_{\mathrm{FL}}$ with C. glabrata, C. parapsilosis and C. tropicalis cells, a cell suspension of $1 \times 10^{5}$ cells $/ \mathrm{mL}$ was prepared in RPMI 1640 . Dilutions of peptide $\mathbf{4}_{\mathrm{FL}}$, a positive kill control with methanol, and a $\beta$-peptide-free control were prepared, and $50 \mu \mathrm{L}$ of each solution was added to an equal volume of cell suspension. Cells were incubated with the solutions for $3.5 \mathrm{~h}$ at $37^{\circ} \mathrm{C}$, PI was added at a final concentration of $1 \mu \mathrm{g} / \mathrm{mL}$ and plates were incubated at $37{ }^{\circ} \mathrm{C}$ for an additional $45 \mathrm{~min}$. Cells were imaged using a fluorescence microscope with a red filter for PI and a blue filter for peptide $\mathbf{4}_{\mathrm{FL}}$.

\subsection{C. albicans Spheroplast Formation and Characterization}

C. albicans cells from overnight cultures $(1 \mathrm{~mL})$ in YDP were pelleted and resuspended in $1 \mathrm{~mL}$ of spheroplasting buffer (0.1 M sodium phosphate, 1.2 M sorbitol, 0.05 M EDTA adjusted to $\mathrm{pH} 8.0)$ and $3.5 \mu \mathrm{L}$ of $\beta$-mercaptoethanol and incubated for $15 \mathrm{~min}$ at room temperature. The solution was pelleted and resuspended in $300 \mu \mathrm{L}$ of spheroplasting buffer and $4.5 \mu \mathrm{L}$ of zymolase and incubated at $37^{\circ} \mathrm{C}$ for $2 \mathrm{~h}$, after which the supernatant was removed and sphroplasts were resuspended in spheroplasting buffer. Spheroplasts were characterized visually by microscopy. Additionally, increasing concentrations of SDS were added to yeast and spheroplast cells and the cells were plated on YPD agar plates to assess cell viability after growth overnight at $37{ }^{\circ} \mathrm{C}$. Spheroplasts were used immediately for planktonic susceptibility experiments.

\subsection{Antifungal Biofilm Susceptibility Testing}

The antifungal activities of the $\beta$-peptides against $C$ andida biofilms were assayed by a method similar to a previously reported protocol [30]. Briefly, overnight cultures of C. albicans SC5314, C. glabrata, C. parapsilosis, and C. tropicalis cells were washed with PBS and re-suspended in RPMI. $100 \mu \mathrm{L}$ of cell suspension adjusted to of $10^{6}$ cells/mL with RPMI 1640 was added to wells of 96-well plates and were statically incubated at $37^{\circ} \mathrm{C}$ for $48 \mathrm{~h}$ to allow biofilm formation. After $48 \mathrm{~h}$ of biofilm formation, biofilms were washed twice with PBS to remove non-adherent cells and $100 \mu \mathrm{L}$ of two-fold serial dilutions of $\beta$-peptides in RPMI were added to the biofilms and plates were incubated at $37^{\circ} \mathrm{C}$ for an additional $48 \mathrm{~h}$. Biofilms were washed with PBS and XTT was used to quantify metabolic activity of biofilms.

\subsection{Biofilm Formation in the Presence of $\beta$-Peptides}

C. albicans, C. glabrata, C. tropicalis, and C. parapsilosis biofilm formation in the presence of $\beta$-peptide was evaluated using a procedure used previously [30]. Briefly, $100 \mu \mathrm{L}$ of overnight cultures of C. albicans SC5314, C. glabrata, C. parapsilosis, and C. tropicalis adjusted to $2 \times 10^{6}$ cells $/ \mathrm{mL}$ was added to $100 \mu \mathrm{L}$ of two-fold serially diluted $\beta$-peptide in a 96-well plates. Peptide-free controls and cell and peptide-free controls were included for each peptide assayed and the plates were incubated at $37^{\circ} \mathrm{C}$ 
for $48 \mathrm{~h}$. After $48 \mathrm{~h}$, biofilms were washed with PBS to remove non-adherent cells and the metabolic activity of biofilms grown in the presence of $\beta$-peptide was determined using XTT.

\subsection{Quantification of Cell Metabolic Activity Using an XTT Assay}

For evaluation of metabolic activities of planktonic cells and biofilms in susceptibility testing in 96-well plates, $100 \mu \mathrm{L}$ of XTT solution was added to every well and plates were incubated at $37{ }^{\circ} \mathrm{C}$ in the dark for $1.5 \mathrm{~h}$ for C. albicans and $2.5 \mathrm{~h}$ for C. glabrata, C. parapsilosis and C. tropicalis. At the end of the incubation, $75 \mu \mathrm{L}$ of supernatant from wells were transferred to a new plate and absorbance at $490 \mathrm{~nm}$ was measured. The percent metabolic activity was calculated as:

$$
\text { Metabolic Activity }(\%)=\frac{\left(A_{490}-A_{490}^{\text {background }}\right)}{A_{490}^{\text {cell control }}-A_{490}^{\text {background }}} \times 100
$$

where $A_{490}, A_{490}^{\text {cell control }}$, and $A_{490}^{\text {background }}$ are the average absorbance values of wells containing a specific concentration of $\beta$-peptide, cell control wells without $\beta$-peptide, and media only wells, respectively. Experiments were performed in triplicate and repeated on at least two different days. Metabolic activity was plotted as a function of $\beta$-peptide concentration and the lowest assayed concentration of $\beta$-peptide that resulted in less than a $10 \%$ average metabolic activity of planktonic cells was taken as the planktonic minimum inhibitory concentration (MIC) of that $\beta$-peptide. Similarly, MICs against existing biofilms and for inhibition of biofilm formation represent the lowest concentrations of $\beta$-peptide that resulted in less than $10 \%$ average metabolic activity of biofilm cells, determined by an XTT assay, normalized to metabolic activity from corresponding untreated control biofilms cultured in a similar manner.

\section{Conclusions}

We have demonstrated that 14 -helical $\beta$-peptides are active against multiple clinical isolates of C. albicans, including a drug-resistant strain, and other opportunistic Candida spp. such as C. glabrata, C. parapsilosis, and $C$. tropicalis. The antifungal activities of $\beta$-peptides directly correlated to the hydrophobicities of the peptides for all strains and species. Additionally, we demonstrated that while the activities of these $\beta$-peptides against existing Candida biofilms were low, they prevented Candida spp. from forming biofilms. The hydrophobicity of the $\beta$-peptides is an important design criterion in biofilm prevention, with more hydrophobic peptides resulting in greater inhibition of biofilm formation. The results of this study demonstrate that globally-amphiphilic hydrophobic $\beta$-peptides can prevent multiple Candida species from forming biofilms, indicating the therapeutic potential of this class of compounds in preventing fungal infections.

\section{Supplementary Materials}

Supplementary materials can be accessed at: http://www.mdpi.com/1424-8247/8/3/483/s1. 


\section{Acknowledgments}

We thank Samuel H. Gellman (UW-Madison) and his lab members for assistance with $\beta$-peptide design, synthesis and characterization. Financial support for this work was provided by the National Institutes of Health (R01 AI092225).

\section{Author Contributions}

N.R., M.R.L., D.M.L, and S.P.P conceived the study; N.R. designed, performed the experiments and analyzed the data; M.R.L. synthesized the peptides; N.R, D.M.L, and S.P.P wrote the paper; D.M.L and S.P.P supervised the entire study.

\section{Conflicts of Interest}

The authors declare no conflict of interest.

\section{References}

1. Wenzel, R.P. Nosocomial candidemia: Risk factors and attributable mortality. Clin. Infect. Dis. 1995, 20, 1531-1534.

2. Brown, G.D.; Denning, D.W.; Gow, N.A.; Levitz, S.M.; Netea, M.G.; White, T.C. Hidden killers: Human fungal infections. Sci. Transl. Med. 2012, 4, doi:10.1126/scitranslmed.3004404.

3. Viscoli, C.; Girmenia, C.; Marinus, A.; Collette, L.; Martino, P.; Vandercam, B.; Doyen, C.; Lebeau, B.; Spence, D.; Krcmery, V.; et al. Candidemia in cancer patients: A prospective, multicenter surveillance study by the invasive fungal infection group (IFIG) of the European organization for research and treatment of cancer (EORTC). Clin. Infect. Dis. 1999, 28, 1071-1079.

4. Concia, E.; Azzini, A.M.; Conti, M. Epidemiology, incidence and risk factors for invasive candidiasis in high-risk patients. Drugs 2009, 69, 5-14.

5. Neofytos, D.; Horn, D.; Anaissie, E.; Steinbach, W.; Olyaei, A.; Fishman, J.; Pfaller, M.; Chang, C.; Webster, K.; Marr, K. Epidemiology and outcome of invasive fungal infection in adult hematopoietic stem cell transplant recipients: Analysis of multicenter prospective antifungal therapy (path) alliance registry. Clin. Infect. Dis. 2009, 48, 265-273.

6. Bodro, M.; Sabe, N.; Gomila, A.; Ayats, J.; Baliellas, C.; Roca, J.; Melilli, E.; Carratala, J. Risk factors, clinical characteristics, and outcomes of invasive fungal infections in solid organ transplant recipients. Transplant. Proc. 2012, 44, 2682-2685.

7. Pfaller, M.; Neofytos, D.; Diekema, D.; Azie, N.; Meier-Kriesche, H.U.; Quan, S.P.; Horn, D. Epidemiology and outcomes of candidemia in 3648 patients: Data from the prospective antifungal therapy (path alliance(r)) registry, 2004-2008. Diagn. Microbiol. Infect. Dis. 2012, 74, 323-331.

8. Shoham, S.; Marr, K.A. Invasive fungal infections in solid organ transplant recipients. Future Microbiol. 2012, 7, 639-655.

9. Kauffman, C.A.; Freifeld, A.G.; Andes, D.R.; Baddley, J.W.; Herwaldt, L.; Walker, R.C.; Alexander, B.D.; Anaissie, E.J.; Benedict, K.; Ito, J.I.; et al. Endemic fungal infections in solid organ and hematopoietic cell transplant recipients enrolled in the transplant-associated infection surveillance network (transnet). Transpl. Infect. Dis. 2014, 16, 213-224. 
10. Kojic, E.M.; Darouiche, R.O. Candida infections of medical devices. Clin. Microbiol. Rev. 2004, 17, 255-267.

11. Cauda, R. Candidaemia in patients with an inserted medical device. Drugs 2009, 69, 33-38.

12. Habash, M.; Reid, G. Microbial biofilms: Their development and significance for medical device-related infections. J. Clin. Pharmacol. 1999, 39, 887-898.

13. Ramage, G.; Saville, S.P.; Thomas, D.P.; Lopez-Ribot, J.L. Candida biofilms: An update. Eukaryotic Cell 2005, 4, 633-638.

14. Ramage, G.; Martinez, J.P.; Lopez-Ribot, J.L. Candida biofilms on implanted biomaterials: A clinically significant problem. FEMS Yeast Res. 2006, 6, 979-986.

15. Ghannoum, M.A.; Rice, L.B. Antifungal agents: Mode of action, mechanisms of resistance, and correlation of these mechanisms with bacterial resistance. Clin. Microbiol. Rev. 1999, 12, 501-517.

16. Sanglard, D.; Odds, F.C. Resistance of Candida species to antifungal agents: Molecular mechanisms and clinical consequences. Lancet. Infect. Dis. 2002, 2, 73-85.

17. Bjarnsholt, T.; Ciofu, O.; Molin, S.; Givskov, M.; Hoiby, N. Applying insights from biofilm biology to drug development-Can a new approach be developed? Nat. Rev. Drug Discov. 2013, 12, 791-808.

18. Mathe, L.; van Dijck, P. Recent insights into Candida albicans biofilm resistance mechanisms. Curr. Genet. 2013, 59, 251-264.

19. Hancock, R.E.; Chapple, D.S. Peptide antibiotics. Antimicrob. Agents Chemother. 1999, 43, 1317-1323.

20. Hancock, R.E.; Sahl, H.G. Antimicrobial and host-defense peptides as new anti-infective therapeutic strategies. Nat. Biotechnol. 2006, 24, 1551-1557.

21. Goldman, M.J.; Anderson, G.M.; Stolzenberg, E.D.; Kari, U.P.; Zasloff, M.; Wilson, J.M. Human beta-defensin-1 is a salt-sensitive antibiotic in lung that is inactivated in cystic fibrosis. Cell 1997, $88,553-560$.

22. Chu, H.L.; Yu, H.Y.; Yip, B.S.; Chih, Y.H.; Liang, C.W.; Cheng, H.T.; Cheng, J.W. Boosting salt resistance of short antimicrobial peptides. Antimicrob. Agents Chemother. 2013, 57, 4050-4052.

23. Porter, E.A.; Wang, X.; Lee, H.S.; Weisblum, B.; Gellman, S.H. Non-haemolytic beta-amino-acid oligomers. Nature 2000, 404, 565.

24. Chongsiriwatana, N.P.; Patch, J.A.; Czyzewski, A.M.; Dohm, M.T.; Ivankin, A.; Gidalevitz, D.; Zuckermann, R.N.; Barron, A.E. Peptoids that mimic the structure, function, and mechanism of helical antimicrobial peptides. Proc. Natl. Acad. Sci. USA 2008, 105, 2794-2799.

25. Chongsiriwatana, N.P.; Miller, T.M.; Wetzler, M.; Vakulenko, S.; Karlsson, A.J.; Palecek, S.P.; Mobashery, S.; Barron, A.E. Short alkylated peptoid mimics of antimicrobial lipopeptides. Antimicrob. Agents Chemother. 2011, 55, 417-420.

26. Ong, Z.Y.; Wiradharma, N.; Yang, Y.Y. Strategies employed in the design and optimization of synthetic antimicrobial peptide amphiphiles with enhanced therapeutic potentials. Adv. Drug Deliv. Rev. 2014, 78, 28-45.

27. Porter, E.A.; Weisblum, B.; Gellman, S.H. Mimicry of host-defense peptides by unnatural oligomers: Antimicrobial $\beta$-peptides. J. Am. Chem. Soc. 2002, 124, 7324-7330. 
28. Raguse, T.L.; Porter, E.A.; Weisblum, B.; Gellman, S.H. Structure-activity studies of 14-helical antimicrobial $\beta$-peptides: Probing the relationship between conformational stability and antimicrobial potency. J. Am. Chem. Soc. 2002, 124, 12774-12785.

29. Karlsson, A.J.; Pomerantz, W.C.; Weisblum, B.; Gellman, S.H.; Palecek, S.P. Antifungal activity from 14-helical $\beta$-peptides. J. Am. Chem. Soc. 2006, 128, 12630-12631.

30. Karlsson, A.J.; Pomerantz, W.C.; Neilsen, K.J.; Gellman, S.H.; Palecek, S.P. Effect of sequence and structural properties on 14-helical $\beta$-peptide activity against Candida albicans planktonic cells and biofilms. ACS Chem. Biol. 2009, 4, 567-579.

31. Lee, M.R.; Raman, N.; Gellman, S.H.; Lynn, D.M.; Palecek, S.P. Hydrophobicity and helicity regulate the antifungal activity of 14-helical $\beta$-peptides. ACS Chem. Biol. 2014, 9, 1613-1621.

32. Silva, S.; Negri, M.; Henriques, M.; Oliveira, R.; Williams, D.W.; Azeredo, J. Adherence and biofilm formation of non-Candida albicans Candida species. Trends Microbiol. 2011, 19, 241-247.

33. Pfaller, M.A.; Andes, D.R.; Diekema, D.J.; Horn, D.L.; Reboli, A.C.; Rotstein, C.; Franks, B.; Azie, N.E. Epidemiology and outcomes of invasive candidiasis due to non-albicans species of Candida in 2,496 patients: Data from the prospective antifungal therapy (path) registry 2004-2008. PloS ONE 2014, 9, doi:10.1371/journal.pone.0101510.

34. Fidel, P.L.; Vazquez, J.A.; Sobel, J.D. Candida glabrata: Review of epidemiology, pathogenesis, and clinical disease with comparison to C. albicans. Clin. Microbiol. Rev. 1999, 12, 80-96.

35. Bizerra, F.C.; Nakamura, C.V.; de Poersch, C.; Estivalet Svidzinski, T.I.; Borsato Quesada, R.M.; Goldenberg, S.; Krieger, M.A.; Yamada-Ogatta, S.F. Characteristics of biofilm formation by Candida tropicalis and antifungal resistance. FEMS Yeast Res. 2008, 8, 442-450.

36. Van Asbeck, E.C.; Clemons, K.V.; Stevens, D.A. Candida parapsilosis: A review of its epidemiology, pathogenesis, clinical aspects, typing and antimicrobial susceptibility. Crit. Rev. Microbiol. 2009, 35, 283-309.

37. Silva, S.; Negri, M.; Henriques, M.; Oliveira, R.; Williams, D.W.; Azeredo, J. Candida glabrata, Candida parapsilosis and Candida tropicalis: Biology, epidemiology, pathogenicity and antifungal resistance. FEMS Microbiol. Rev. 2012, 36, 288-305.

38. Cuellar-Cruz, M.; Lopez-Romero, E.; Villagomez-Castro, J.C.; Ruiz-Baca, E. Candida species: New insights into biofilm formation. Future Microbiol. 2012, 7, 755-771.

39. Hamuro, Y.; Schneider, J.P.; DeGrado, W.F. De novo design of antibacterial beta-peptides. J. Am. Chem. Soc. 1999, 121, 12200-12201.

40. Kim, S.; Kim, S.S.; Lee, B.J. Correlation between the activities of alpha-helical antimicrobial peptides and hydrophobicities represented as RP HPLC retention times. Peptides 2005, 26, 2050-2056.

41. Jiang, Z.; Kullberg, B.J.; van der Lee, H.; Vasil, A.I.; Hale, J.D.; Mant, C.T.; Hancock, R.E.; Vasil, M.L.; Netea, M.G.; Hodges, R.S. Effects of hydrophobicity on the antifungal activity of $\alpha$-helical antimicrobial peptides. Chem. Biol. Drug Des. 2008, 72, 483-495.

42. Liu, R.H.; Chen, X.; Falk, S.P.; Mowery, B.P.; Karlsson, A.J.; Weisblum, B.; Palecek, S.P.; Masters, K.S.; Gellman, S.H. Structure-activity relationships among antifungal nylon-3 polymers: Identification of materials active against drug-resistant strains of Candida albicans. J. Am. Chem. Soc. 2014, 136, 4333-4342.

43. Liu, R.; Chen, X.; Falk, S.P.; Masters, K.S.; Weisblum, B.; Gellman, S.H. Nylon-3 polymers active against drug-resistant Candida albicans biofilms. J. Am. Chem. Soc. 2015, 137, 2183-2186. 
44. Andes, D.; Nett, J.; Oschel, P.; Albrecht, R.; Marchillo, K.; Pitula, A. Development and characterization of an in vivo central venous catheter Candida albicans biofilm model. Infect. Immun. 2004, 72, 6023-6031.

45. Pereira, H.A.; Tsyshevskaya-Hoover, I.; Hinsley, H.; Logan, S.; Nguyen, M.; Nguyen, T.T.; Pohl, J.; Wozniak, K.; Fidel, P.L. Candidacidal activity of synthetic peptides based on the antimicrobial domain of the neutrophil-derived protein, CAP37. Med. Mycol. 2010, 48, 263-272.

46. Tavanti, A.; Maisetta, G.; del Gaudio, G.; Petruzzelli, R.; Sanguinetti, M.; Batoni, G.; Senesi, S. Fungicidal activity of the human peptide hepcidin 20 alone or in combination with other antifungals against Candida glabrata isolates. Peptides 2011, 32, 2484-2487.

47. Grieco, P.; Carotenuto, A.; Auriemma, L.; Limatola, A.; Di Maro, S.; Merlino, F.; Mangoni, M.L.; Luca, V.; Di Grazia, A.; Gatti, S.; et al. Novel $\alpha$-msh peptide analogues with broad spectrum antimicrobial activity. PloS ONE 2013, 8, doi:10.1371/journal.pone.0061614.

48. Wimley, W.C. Describing the mechanism of antimicrobial peptide action with the interfacial activity model. ACS Chem. Biol. 2010, 5, 905-917.

49. Wang, G. Human antimicrobial peptides and proteins. Pharmaceuticals 2014, 7, 545-594.

50. Raguse, T.L.; Lai, J.R.; Gellman, S.H. Environment-independent 14-helix formation in short $\beta$-peptides: Striking a balance between shape control and functional diversity. J. Am. Chem. Soc. 2003, 125, 5592-5593.

51. Lee, M.R.; Raguse, T.L.; Schinnerl, M.; Pomerantz, W.C.; Wang, X.; Wipf, P.; Gellman, S.H. Origins of the high 14-helix propensity of cyclohexyl-rigidified residues in beta-peptides. Org. Lett. 2007, 9, 1801-1804.

52. Vaz, E.; Pomerantz, W.C.; Geyer, M.; Gellman, S.H.; Brunsveld, L. Comparison of design strategies for promotion of beta-peptide 14-helix stability in water. Chembiochem. 2008, 9, 2254-2259.

53. Jang, W.S.; Bajwa, J.S.; Sun, J.N.; Edgerton, M. Salivary histatin 5 internalization by translocation, but not endocytosis, is required for fungicidal activity in Candida albicans. Mol. Microbiol. 2010, 77, 354-370.

54. Puri, S.; Edgerton, M. How does it kill?: Understanding the candidacidal mechanism of salivary histatin 5. Eukaryotic Cell 2014, 13, 958-964.

55. Mohanram, H.; Bhattacharjya, S. Resurrecting inactive antimicrobial peptides from the lipopolysaccharide trap. Antimicrob. Agents Chemother. 2014, 58, 1987-1996.

56. de la Fuente-Nunez, C.; Korolik, V.; Bains, M.; Nguyen, U.; Breidenstein, E.B.; Horsman, S.; Lewenza, S.; Burrows, L.; Hancock, R.E. Inhibition of bacterial biofilm formation and swarming motility by a small synthetic cationic peptide. Antimicrob. Agents Chemother. 2012, 56, 2696-2704.

57. Bonhomme, J.; d'Enfert, C. Candida albicans biofilms: Building a heterogeneous, drug-tolerant environment. Curr. Opin. Microbiol. 2013, 16, 398-403.

58. Taff, H.T.; Nett, J.E.; Zarnowski, R.; Ross, K.M.; Sanchez, H.; Cain, M.T.; Hamaker, J.; Mitchell, A.P.; Andes, D.R. A Candida biofilm-induced pathway for matrix glucan delivery: Implications for drug resistance. PLoS Pathog. 2012, 8, doi:10.1371/journal.ppat.1002848.

59. Karlsson, A.J.; Flessner, R.M.; Gellman, S.H.; Lynn, D.M.; Palecek, S.P. Polyelectrolyte multilayers fabricated from antifungal $\beta$-peptides: Design of surfaces that exhibit antifungal activity against Candida albicans. Biomacromolecules 2010, 11, 2321-2328. 
60. Helmerhorst, E.J.; Venuleo, C.; Beri, A.; Oppenheim, F.G. Candida glabrata is unusual with respect to its resistance to cationic antifungal proteins. Yeast 2005, 22, 705-714.

61. Singh, A.; Prasad, T.; Kapoor, K.; Mandal, A.; Roth, M.; Welti, R.; Prasad, R. Phospholipidome of Candida: Each species of Candida has distinctive phospholipid molecular species. Omics 2010, 14, 665-677.

62. Murray, J.K.; Gellman, S.H. Application of microwave irradiation to the synthesis of 14-helical beta-peptides. Org. Lett. 2005, 7, 1517-1520.

63. Mitchell, K.F.; Taff, H.T.; Cuevas, M.A.; Reinicke, E.L.; Sanchez, H.; Andes, D.R. Role of matrix beta-1,3 glucan in antifungal resistance of non-albicans Candida biofilms. Antimicrob. Agents Chemother. 2013, 57, 1918-1920.

(C) 2015 by the authors; licensee MDPI, Basel, Switzerland. This article is an open access article distributed under the terms and conditions of the Creative Commons Attribution license (http://creativecommons.org/licenses/by/4.0/). 